\title{
Role of FAK Phosphorylation in Cobalt Chloride-Induced Epithelial-to-Mesenchymal- Like Transition
}

Ju-Ock Nam*

Department of Ecological Environment Conservation, Kyungpook National University, Sangiu 742-711, Korea

Received November 29, 2010 / Accepted January 10, 2011

\begin{abstract}
Hypoxia is a common condition found in a wide range of solid tumors and is often associated with metastasis and poor clinical outcomes. In the present study, we found that HIF-1a was induced by cobalt chloride $(500 \mu \mathrm{M})$ treatment on human lung cancer cells, A549 and H460, for 24 hr. However, cobalt chloride $(500 \mu \mathrm{M})$ did not affect cell proliferation of A549 and H460 in $48 \mathrm{hr}$. Cobalt chloride $(500 \mu \mathrm{M})$ additionally induced epithelial-to-mesenchymal-like transition (EMT) such as reduced E-cadherin expression and increased a-SMA expression. These results were confirmed by immunofluorecence experiment in H460 cells. E-cadherin was localized on the outer cell membrane. However, when the cells were treated with $500 \mu \mathrm{M}$ cobalt chloride for $24 \mathrm{hr}$, diffuse E-cadherin staining was observed, characteristic of a migratory mesenchymal phenotype. We also found that cobalt chloride induced integrin $\beta 3$ expression and FAK phosphorylation in human lung cancer cells using western blotting and FACS anlaysis. Our data suggest that integrin $\beta 3$-induced FAK phosphorylation may be developed into target molecules for blocking tumor metastasis.
\end{abstract}

Key words : Hypoxia, epithelial-to-mesenchymal-like transition (EMT), integrin, FAK, cobalt chloride

\section{서 론}

대부분의 암환자의 가장 큰 사망 요인은 암의 전이이다. 암의 전이는 여러 단계로 구분되는 과정을 통해 일어나는데, 악성화된 상피세포가 세포간 유착을 소실하여 이동성을 획 득하는 invasion 단계와 암세포가 혈관이나 림프관을 똟고 들어가는 intravasation 단계, 전신 순환계로 들어온 암세포 가 본래 조직이 아닌 다른 기관에 정착하기 위해서는 전신 순환계에서 모세혈관을 뜷고 나오는 extravasation을 거쳐 마 지막으로 새로운 숙주 환경에서 자랄 수 있는 능력을 갖추게 되면 극히 일부의 악성암세포가 제 2의 종양을 형성하게 된 다[6,13]. 암의 전이의 첫 단계인 invasion 단계를 거치기 위해 서는 세포-세포간 부착의 저해가 수반되어야 하는데 이런 현 상은 epithelial-to-mesenchymal-like transition (EMT)의 현 상과 비슷하다. 여러 가지 암유전자 신호전달 물질들 $(\mathrm{Src}$, Ras, Ets, integrin, Wnt/beta-catenin and Notch)이 EMT를 유도한다고 보고되었다[2,8,12,23,25]. 특히나 Ras-MAPK는 Snail과 Slug와 같은 전사인자를 활성화 함으로써 E-cadherin 의 전사를 저해하고 이로써 $\mathrm{EMT}$ 를 촉진한다고 잘 알려져 있 다[19,21,22]. 최근 연구에서는 phosphatidylinositol 3' kinase (PIKK)/AKT axis의 활성이 EMT를 유도하는데 가장 중추적인 역할을 한다는 보고가 발표되었다[3,7,10].

국소부착 카이네이즈(Focal adhesion kinase; FAK)은 세포

*Corresponding author

Tel : +82-54-530-1363, Fax : +82-54-530-1369

E-mail : namjo@knu.ac.kr
내 타이로신 카이네이즈 단백질(cytoplasmic protein-tyrosine kinase; RTK)로서 인테그린(integrin) 및 여러 성장 인자 수용 체에 의해 매개되는 세포이동과 생존을 매개하는 중요한 단백 질이다. 이와 같은 국소부착 카이네이즈는 397번 타이로신 잔 기가 인산화 되어 이를 매개하는 Src-family kinase의 SH2 도 메인이 결합 함으로써 FAK-Src 신호전달을 매개한다[2,8]. $\mathrm{FAK}$ 은 인간 종양 샘플과 종양에서 유래된 세포주의 발현이 전립선(prostate), 유방(breast), 대장(colon), 난소(ovarian), 폐 (lung) 그리고 갑상선(thyroid)과 같은 여러 조직의 암화 과정 그리고 암세포 전이 동안 발현과 인산화가 증가되어 있다고 알려져 있다[2,8,10]. 뿐만 아니라, FAK은 PI3K/PKD1/Akt/ $\mathrm{PKB}$ 및 Grb2/SOS/Ras/Raf-1/MEK/ERK을 통하여 세포의 성장 및 생존/사멸을 조절한다고 알려져 있다[24,27].

저 산소 상태(hypoxia)는 체내 조직 내 산소가 고갈된 상 태로 조직에서 필요한 양만큼 산소가 공급되지 못하는 현상 을 말한다. 저산소증은 조직에 산소가 전혀 공급이 안 되는 무산소증(anoxia)과 동맥혈의 산소 분압이 낮은 저산소혈증 (hypoxemia)과는 구분된다. 저산소증은 다양한 고형종양 (solid tumor)에서 발견되는 대표적인 생리 현상으로 환자의 나쁜 예후를 나타내는 지표로도 사용되고 있다[11,14,28]. 암 세포의 빠른 증식은 저 산소 상태를 유발하게 되고, 이 과정 에서 대부분의 암세포에 과도하게 발현되는 저 산소 유도 인 자(Hypoxia-inducible factor $1 ; \mathrm{HIF}-1)$ 가 활성화 된다. HIF-1 은 HIF-1a와 HIF-1 $\beta$ 라는 두 subunit이 heterodimer를 형성 하고 있다[11]. HIF-1a는 세포질 내에 존재하면서 normoxic 상태에서는 급격히 분해되고, 저 산소 상태에서는 안정화되 
어 농도가 증가한다. 저 산소 상태에서 증가된 HIF- $1 \mathrm{a}$ 가 HIF-1 $\beta$ 와 dimer를 형성 하여 세포질에서 핵 내로 이동하게 되어 종양의 성장과 분화에 관여하는 단백질의 promotor로 작용한다[11].

따라서 본 연구는, 저 산소 상태를 mimic하는 화합물로 주 로 사용되고 있는 cobalt chloride $\left(\mathrm{CoCl}_{2}\right)$ 로 유도한 저 산소 상태에서 발생하는 인간 폐암세포 EMT 과정에서의 FAK 활 성의 영향을 밝힘으로써 FAK의 새로운 기능을 규명하고 더 나아가 암의 전이의 저해 타겟 물질 후보로서 FAK을 제시하 고자 한다.

\section{재료 및 방법}

\section{세포배양 및 저 산소 상태 유도}

인간 폐암세포(A549)와 비소세포폐암세포주(H460)를 경북 대학교 의과대학 생화학교실로부터 분양 받아 본 실험실에서 배양하면서 실험에 사용하였다. A549와 H460세포를 100 units/ml의 penicillin-streptomycin (GIBCO, USA)과 $10 \% \mathrm{FBS}$ (Hyclone, USA)가 함유된 RPMI 1640 (invitrogen, USA)을 사 용하여 $37^{\circ} \mathrm{C}, 5 \% \mathrm{CO}_{2}$ 배양기에서 배양하였다. 배양 중인 세포 는 2-3일에 한번씩 새로운 배지로 바꿔주었다. 저 산소 상태를 유도하기 위해서, A549와 H460 세포를 FBS가 없는 RPMI1640 배지에서 하루 동안 키운 후, 100-500 $\mathrm{\mu M}$ 의 $\mathrm{CoCl}_{2}$ (Sigma Chemical Co., USA)를 포함한 RPMI 1640 배지에서 12시간 배양하였다.

\section{MTT assay}

$\mathrm{A} 549$ 와 $\mathrm{H} 460$ 세포에 $\mathrm{CoCl}_{2}$ 를 적정농도로 처리하고 6-48 시간 동안 배양한 후 배지를 제거하고 tetrazolium bromide salt (MTT, Sigma Chemical Co., USA)를 $0.5 \mathrm{mg} / \mathrm{ml}$ 농도로 희석하여 $200 \mu \mathrm{l}$ 씩 분주하고 3-4시간 동안 다시 배양하였다. 배양이 끝난 다음 $\mathrm{MTT}$ 시약을 제거하고 $\mathrm{DMSO}$ 를 $1 \mathrm{ml}$ 씩 분주하여 well에 생성된 formazin를 모두 녹인 후 96 well plate에 $200 \mu \mathrm{l}$ 씩 옮겨서 ELISA reader로 $540 \mathrm{~nm}$ 에서 흡광 도를 측정하였다. 이 흡광도는 MTT가 세포에 의해서 환원된 양을 나타내며, 따라서 각 well에 존재하는 생존 세포수와 비 례한다.

\section{Western blot analysis}

다양한 조건으로부터 준비된 세포들을 모은 다음, lysis buffer [50 mmol/1 Tri-HCl (pH 7.4); 1\% NP40; 150 mmol/1 $\mathrm{NaCl} ; 1 \mathrm{mmol} / 1$ EDTA; $1 \mathrm{mmol} / 1$ phenylmethylsulfonyl fluoride; $1 \mathrm{mmol} / 1 \mathrm{Na}_{3} \mathrm{VO}_{4}$; and $5 \mathrm{mg} / \mathrm{ml}$ each of aprotinin, leupeptin, and pepstatin] 을 첨가하여 $4^{\circ} \mathrm{C}$ 에서 1 시간 동안 반응 시킨 후, $13,000 \mathrm{rpm}$ 으로 10 분간 원심분리 하여 그 상층 액을 취하였다. 상층액의 단백질 농도는 Bio-Rad 단백질 정량
시약 사용방법에 따라 정량 한 다음 Laemmli sample buffer를 섞어서 sample을 만들었다. 이렇게 만든 동량의 단백질을 sodium dodecyl sulphate (SDS)-polyacrylamide gel를 이용하 여 전기영동으로 분리한 다음 polyvinylidene difluoride membranes 으로 electroblotting 에 의해 membrane으로 전이 시켰다. 전이가 끝난 membrane에 $5 \% \mathrm{BSA}$ 가 포함되어 있는 TBST buffer (50 mM Tris- $\mathrm{HCl}, 150 \mathrm{mM} \mathrm{NaCl}$, and $0.05 \%$ Tween 20)을 이용하여 상온에서 1시간 동안 blocking을 시켰 다. Blocking이 끝난 membrane에 1차 항체를 처리하여 $4^{\circ}$ 에 서 16 시간 반응시킨 다음 2 차 항체를 사용하여 상온에서 1 시 간 정도 반응시켰다. 반응이 끝난 후 TBST buffer로 충분히 세척하고 Enhanced Chemiluminoesence (ECL) 용액 (Amersham Pharmacia Biotech., USA)을 적용 시킨 다음 암실 에서 X-ray film에 감광시켜 특정 단백질의 양을 분석하였다.

\section{FACS anlaysis}

다양한 조건으로 준비된 세포를 $0.25 \% \operatorname{trypsin} / 0.05 \%$ EDTA를 이용하여 세포를 모은 후, phosphate buffered saline (PBS)로 두 번 washing을 한다. Washing이 끝난 세포를 $0.1 \mathrm{ml} \mathrm{PBS}$ 에 현탁 시킨 후 실험에 맞는 특이한 항체를 첨 가하여 $4^{\circ} \mathrm{C}$ 에서 1 시간 정도 반응을 한다. 반응이 끝난 후 10 $\mu \mathrm{g} / \mathrm{ml}$ 농도의 형광이 달린 이차항체를 첨가하여 $4^{\circ} \mathrm{C}$ 에서 1 시간 반응한 후, Flow Cytometer FACScalibur system (BD Biosciences)를 이용하여 분석한다.

\section{Immunofluorescence assay}

세포를 chamber slide에 키운 후, 3.7\% formaldehyde을 상온에서 10 분간 반응하여 세포를 고정시킨다. 고정된 세포 에 $0.25 \%$ Triton X-100을 상온에서 5분간 처리함으로써 세포 를 permeablization된 상태로 만든 후, E-cadherin (1:100)과 DAPI (1:5000) 일차항체를 $4^{\circ} \mathrm{C}$ 에서 16 시간 정도 반응 후 형 광이 달린 2 차 항체를 상온에서 1 시간 반응한다. 반응이 끝 난 샘플은 antifading 용액으로 mounting 한 후 Axiophot microscope (Zeiss, Thornwood, NY)를 이용하여 이미지를 얻었다.

\section{결과 및 고찰}

\section{인간 폐암 세포에서 $\mathrm{CoCl}_{2}$ 처리에 의한 $\mathrm{HIF-1a}$ 변화}

세포 배양 실험에서 생리적 저산소증과 유사하게 만들기 위한 산소의 농도는 일반적으로 $1-5 \%$ 이며, 이를 위하여 heme moiety에 있는 철(iron)을 대치하여 환원상태를 지속시켜 저 산소증과 유사한 상태를 만드는 전이금속원소인 $\mathrm{CoCl}_{2}$ 를 사 용하였다. 인간 폐암세포(A549)에서의 저 산소 상태 조건을 최적화 하기 위해 다양한 농도의 $\mathrm{CoCl}_{2}$ 를 처리 후 $\mathrm{HIF}-1 \mathrm{a}$ 의 발현 정도를 조사하였다. 그 결과, $\mathrm{CoCl}_{2}$ 농도 의존적으로 
HIF-1a의 발현이 증가함을 확인 할 수 있었고, $500 \mu \mathrm{M}$ 에서 최고의 HIF-1a의 발현 증가를 확인 하였다(Fig. 1A). 따라서, 인간 폐암 세포, $\mathrm{A} 549$ 와 $\mathrm{H} 460$ 에 $500 \mu \mathrm{M} \mathrm{CoCl}$ 를 24시간 처리 한 후 HIF-1a의 유도를 다시 확인해 본 결과, 두 세포 모두에서 HIF-1a 발현의 증가를 확인 하였다(Fig. 1B).

\section{인간 폐암 세포 증식 억제 효과}

Ardyanto [1], Corley [5] 그리고 Lee [9]의 연구에서는, $\mathrm{CoCl}_{2}$ 를 암세포 및 vascular smooth muscle 세포에 처리하였 을 때 유도 되는 HIF-1a에 의해 암세포의 증식 및 사멸 그리고

A

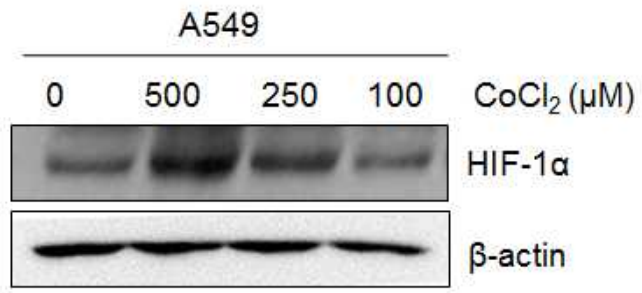

B

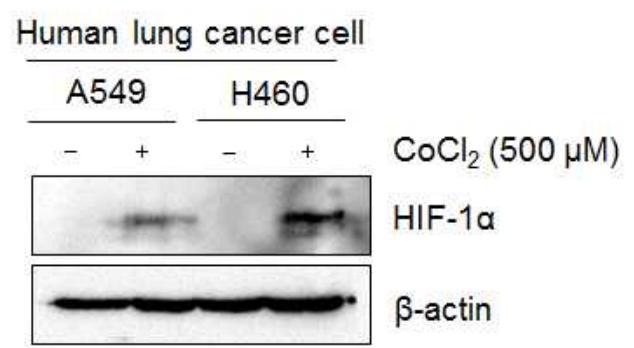

Fig. 1. Effects of $\mathrm{CoCl}_{2}$ treatment on the levels of HIF-1a expression in human lung cancer cells. A549 cells were incubated with various concentrations of $\mathrm{CoCl}_{2}$ for 24 hr (A) or A549 and H460 cells were incubated with 500 $\mathrm{uM} \mathrm{CoCl} 2$ for $24 \mathrm{hr}(\mathrm{B})$. The cells were lysed and then cellular proteins were separated by SDS-polyacrylamide gels and transferred onto nitro-cellulose membranes. The membranes were probed with the indicated antibodies. Proteins were visualized using an ECL detection system. Actin was used as an internal control. vascular smooth muscle 세포의 부착 및 이동에 영향을 미친 다고 발표된 바 있다. 따라서 본 연구에서는 HIF-1a의 유도를 위해 사용한 $500 \mu \mathrm{M} \mathrm{CoCl}_{2}$ 에 의해서 인간 폐암 세포 증식에 영향을 미치는지를 알아보기 위해 MTT assay를 행하였다. 인 간 폐암세포, $\mathrm{A} 549$ 와 $\mathrm{H} 460$ 에 $500 \mu \mathrm{M} \mathrm{CoCl}$ 를 시간 별로 처 리한 후 MTT assay 행한 결과, 두 세포 모두에서 $500 \mathrm{uM}$ $\mathrm{CoCl}_{2}$ 에 의한 어떠한 세포 증식에 대한 영향을 확인 할 수 없었다(Fig. 2A-B). 이 결과는 본 연구에 사용한 저 산소 상태 유도 조건이 두 인간 폐암 세포에 cytotoxicity 영향은 없음을 시사한다.

\section{인간 폐암 세포에서 $\mathrm{CoCl}_{2}$ 처리에 의한 EMT}

다양한 암세포들은 세포-세포간 결합에 관여하는 단백질 중 하나인 E-cadherin의 발현이 줄어 듬으로써 암세포의 EMT 가 일어나고 최종적으로 전이를 유발한다는 보고가 있다 $[12,20]$. 뿐만 아니라, 암세포를 둘러싸고 있는 미세환경 중 대 표적인 특징이 저 산소 상태이고, 저 산소 상태에 노출된 암세 포는 악성화 된다는 보고가 있다[6,11]. 이러한 악성 암세포의 특징은 전이가 일어난다는 것으로써, 암세포 전이를 위해서는 먼저 세포-세포 간 부착력이 감소하고 세포의 운동성이 증가 하여야 하며, 세포와 세포, 세포와 기질간의 상호작용에 관여 하는 유착 물질로 integrin, cadherin, immunoglobulin superfamily와 selectin의 4 가지 군이 알려져 있다[4,15,16,17]. 이들 중 E-cadherin은 세포와 세포의 상호간의 인식과 조직의 형태 유지 등에 가장 중요한 역할을 한다는 보고가 있다[12,20]. 따 라서, 본 연구에서 저 산소 상태에서의 세포-세포 간 부착력을 조사하고자, $500 \mu \mathrm{M} \mathrm{CoCl}_{2}$ 를 24시간 처리한 인간 폐암세포에 서의 E-cadherin 발현 및 세포막의 존재 양상을 보기 위하여 웨스턴 및 형광염색 실험을 통하여 알아보았다. 그 결과, 500 $\mu \mathrm{M} \mathrm{CoCl} 2$ 를 24시간 처리한 인간 폐암세포, $\mathrm{H} 460$ 에서 E-cadherin 발현양이 감소함을 확인하였다(Fig. 3A-B). 그리고 Normoxia 상태의 인간 폐암세포, H460에서의 E-cadherin 형 광염색은 세포-세포 간 junction 부위에 균일하게 나타나는 반 면, $500 \mu \mathrm{M} \mathrm{CoCl}_{2}$ 처리한 $\mathrm{H4} 60$ 세포는 세포-세포 간 junction
A

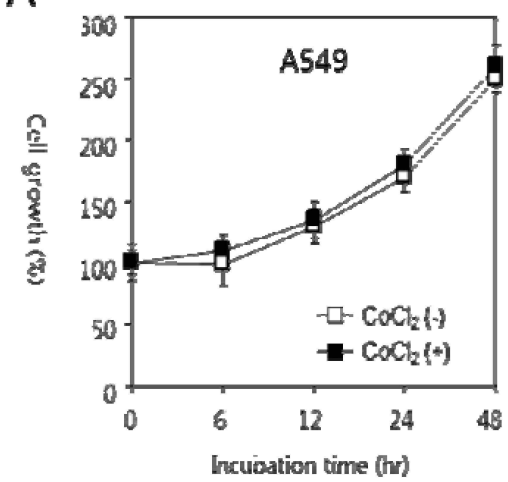

B

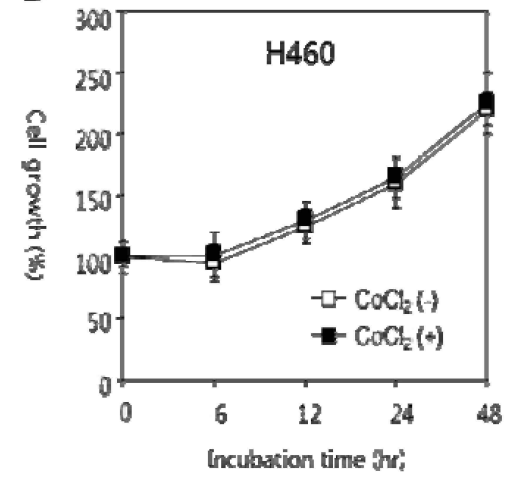

Fig. 2. Effects of $\mathrm{CoCl}_{2}$ treatment on the cell growth of human lung cancer cells, A549 (A) and H460 (B). The cells were incubated with $500 \mu \mathrm{M} \mathrm{CoCl}_{2}$ for indicated times. The rate of cell growth was measured by metabolic-byebased MTT assay. 
A

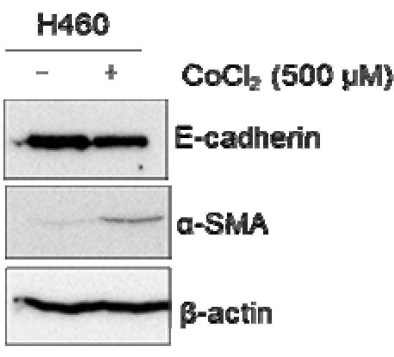

B

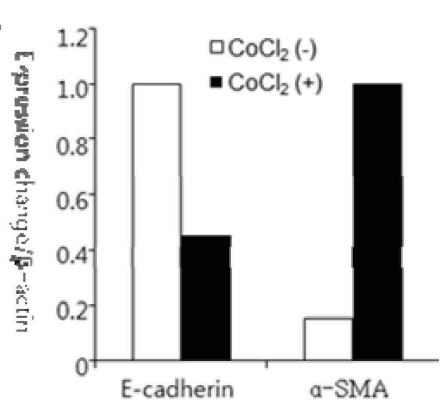

A

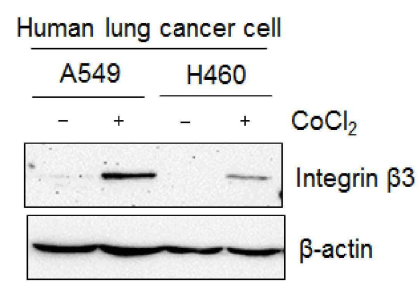

B
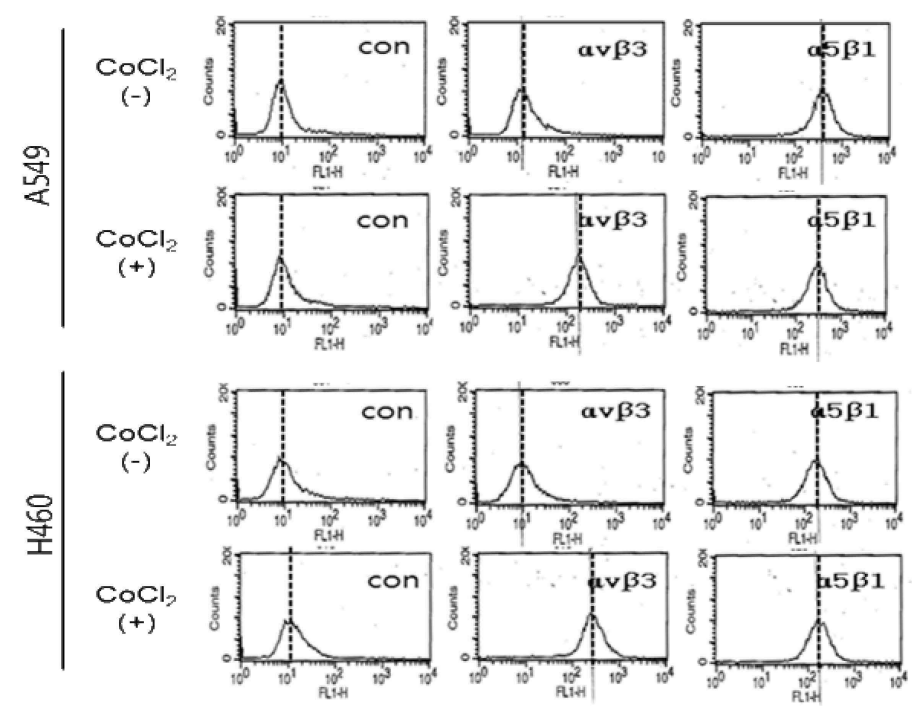

Fig. 3. Effects of $\mathrm{CoCl}_{2}$ treatment of EMT on $\mathrm{H} 460$ cells. (A) H460 cells were incubated with $500 \mu \mathrm{M} \mathrm{CoCl} 2$ for $24 \mathrm{hr}$. The cells were lysed and then cellular proteins were separated by SDS-polyacrylamide gels and transferred onto nitro-cellulose membranes. The membranes were probed with the indicated antibodies. Proteins were visualized using an ECL detection system. Actin was used as an internal control. (B) Protein levels of E-cadherin and a-SMA were normalized by beta-actin protein. (C) H460 cells were incubated with $500 \mu \mathrm{M}$ $\mathrm{CoCl}_{2}$ for $24 \mathrm{hr}$. The cells were seeded in a LabTek chamber slide (Nunc., Denmark) and incubated overnight. Cells in the coverslip were fixed with $0.25 \%$ Triton X-100 and stained with anti-E-cadherin (1:100) and anti-DAPI (1:5000). Chambers slips were mounted with antifading solution and images were obtained on an Axiophot microscope.

Fig. 4. Effect of $\mathrm{CoCl}_{2}$ treatment of Integrin $\beta$ 3-FAK pathway. (A, C) A549 and H460 cells were incubated with $500 \mu \mathrm{M} \mathrm{CoCl}$ for 24hr. The cells were lysed and then cellular proteins were separated by SDS-polyacrylamide gels and transferred onto nitro-cellulose membranes. The membranes were probed with the indicated antibodies. Proteins were visualized using an ECL detection system. Actin was used as an internal control. (B) Flow cytometric analysis was done on cells stained with saturating concentration of the following monoclonal antibodies: av $\beta 3$ (MAB1976), a5ß1 (MAB1999). Cell number (y-axis) plotted as a function of fluorescence intensity (x-axis). Negative control cells were incubated with the secondary antibody alone. 
부위가 깨어져 있는 형광염색 결과를 확인 하였다(Fig. 3C). 뿐만 아니라, EMT 동안 세포의 운동성이 증가하기 위해서는, elongated shape, mesenchymal 마커의 발현등과 같은 fibroblast-like 세포의 특징 필요하고 이 특징 중 대표하는 마커가 alpha-smooth muscle actin (a-SMA)의 발현 증가라는 보고가 많이 있다[20]. 따라서 본 연구에서는 $500 \mu \mathrm{M} \mathrm{CoCl} 2$ 를 24시간 처리한 인간 폐암세포, $\mathrm{H} 460$ 에서의 a-SMA의 발현양을 조사 하였다. 그 결과, $\mathrm{CoCl}_{2}$ 처리한 인간 폐암세포, $\mathrm{H} 460$ 에서 a -SMA의 발현양이 증가함을 확인하였다(Fig. 3A-B).

\section{$\mathrm{CoCl}_{2}$ 처리에 의한 EMT의 기전 규명}

Ryu [16]와 Chung [4]의 연구에서는, 저 산소 상태의 편평 암세포(oral squamous cell) 와 유방암 세포(breast carcinoma cell)에서 alpha 5 그리고 alpha6beta1 integrin의 발현이 증가 함으로써 암세포의 invasion을 증가 시켰다고 보고하였다. 따 라서 본 연구는 폐암세포에서 $\mathrm{CoCl}_{2}$ 처리에 의한 저 산소 상태 에 의해 유도되는 $\mathrm{EMT}$ 의 기전을 규명하고자, $500 \mu \mathrm{M} \mathrm{CoCl} 2$ 를 24시간 처리한 인간 폐암세포, A549와 H460에서의 integrin의 발현 변화를 FACS anlaysis로 조사하였다. 그 결과, Normoxia 상태에서는 전혀 나타나지 않던 integrin $\beta 3$ 의 발현이 $\mathrm{CoCl}_{2}$ 처리한 인간 폐암세포에서 integrin $\beta 3$ 의 발현양이 증가하는 것을 확인하였다(Fig. 4A-B). 뿐만 아니라, 지금까지 알려진 보고에 의하면 저 산소 상태에서 EMT가 일어 날 때, 세포내의 PI3K-AKT 단백질의 활성이 중요한 역할을 한다고 알려져 있 고[18,26], FAK 단백질이 integrin의 하부에서 그리고 PISK-AKT의 상부 신호전달 단백질로서 암 화 과정에 중요한 역할을 한다고 잘 알려져 있다[18,24,26]. 따라서 $\mathrm{CoCl}_{2}$ 처리한 인간 폐암세포에서의 인테그린 하부 신호전달 물질을 조사하 기 위해, $\mathrm{FAK}$ 의 활성 정도를 확인한 결과, $\mathrm{CoCl}_{2}$ 에 의한 저 산소 상태에서 $\mathrm{FAK}$ 의 총 발현양은 변화가 없는데 반하여 $\mathrm{FAK}$ 의 인산화가 증가함으로써 활성 또한 증가된다는 것을 확인하였다(Fig. 4C). 본 연구 결과로서 저 산소 상태에 노출된 인간 폐암세포가 세포막에 있는 integrin $\beta 3$ 의 발현양의 증가 에 의한 FAK의 활성 증가로 $\mathrm{EMT}$ 가 됨으로써 악성 암세포로 전환 될 가능성이 있음을 확인하였다. 본 연구는 $\mathrm{FAK}$ 의 활성 을 조절 함으로써 암세포의 악성화를 저해할 가능성이 있음을 시사하는 바이다.

\section{감사의 글}

이 논문은 2010학년도 경북대학교 신임교수정착연구비에 의하여 연구되었습니다.

\section{References}

1. Ardyanto, T. D., M. Osaki, Y. Nagahama, K. Yamaga, N.
Maeta, T. Tamura, and H. Ito. 2008. Down-regulation of cobalt-induced HIF-1alpha expression correlates with cell proliferation and apoptosis in human gastric carcinoma cells. Oncol. Rep. 19, 339-343.

2. Avizienyte, E., and M. C. Frame. 2005. Src and FAK signaling controls adhesion fate and the epithelial-to-mesenchymal transition. Curr. Opin. Cell Biol. 17, 542-547.

3. Benelli, R., S. Monteghirfo, R. Vene, F. Tosetti, and N. Ferrari. 2010. The chemopreventive retinoid 4HPR impairs prostate cancer cell migration and invasion by interfering with FAK/AKT/GSK3beta pathway and beta-catenin stability. Mol. Cancer 9, 142-155.

4. Chung, J., S. Yoon, K. Datta, R. E. Bachelder, and A. M. Mercurio. 2004. Hypoxia-induced vascular endothelial growth factor transcription and protection from apoptosis are dependent on alpha6beta1 integrin in breast carcinoma cells. Cancer Res. 64, 4711-4716.

5. Corley, K. M., C. J. Taylor, and B. Lilly. 2005. Hypoxia-inducible factor 1a modulates adhesion, migration, and FAK phosphorylation in vascular smooth muscle cells. J. Cell Biochem 96, 971-985.

6. Finger, E. C. and A. J. Giaccia. 2010. Hypoxia, inflammation, and the tumor microenvironment in metastatic disease. Cancer Metastasis Rev. 29, 285-293.

7. Guan, F., L. Schaffer, K. Handa, and S. I. Hakomori. 2010. Functional role of gangliotetraosylceramide in epithelial-to-mesenchymal transition process induced by hypoxia and by TGF-\{beta\}. FASEB J. 24, 4889-4903.

8. Guarino, M. 2010. Src signaling in cancer invasion. J. Cell Physiol. 223, 14-26.

9. Lee, M., A. Lapham, M. Brimmell, H. Wilkinson, and G. Packharm. 2008. Inhibition of proteasomal degradation of Mcl-1 by cobalt chloride suppresses cobalt chloride-induced apoptosis in HCT116 colorectal cancer cells. Apoptosis 13, 972-982.

10. Lee, S. H., Y. J. Lee, and H. J. Han. 2011. Role of hypoxia-induced fibronectin-integrin beta1 expression in embryonic stem cell proliferation and migration: Involvement of PI3K/Akt and FAK. J. Cell Physiol. 226, 484-493.

11. Lu, X. and Y. Kang. 2010. Hypoxia and hypoxia-inducible factors (HIFs): master regulators of metastasis. Clin Cancer Res. 24, 5928-5935.

12. Mandal, M., J. N. Myers, S. M. Lippman, F. M. Johnson, M. D. Williams, S. Rayala, K. Ohshiro, D. I. Rosenthal, R. S. Weber, G. E. Gallick, and A. K. EI-Naggar. 2008. Epithelial to mesenchymal transition in head and neck squamous carcinoma: association of Src activation with E-cadherin down-regulation, vimentin expression, and aggressive tumor features. Cancer 112, 2088-2100.

13. Milani, M. and A. L. Harris. 2008. Targeting tumour hypoxia in breast cancer. Eur. J. Cancer 44, 2766-2773.

14. Munoz-najar, U. M., K. M. Neurath, F. Vumbaca, and K. P. Claffey. 2006. Hypoxia stimulates breast carcinoma cell invasion through MT1-MMP and MMP-2 activation. Oncogene 25, 2379-2392.

15. Rohwer, N., M. Welzel, K. Daskalow, D. Pfander, B. Wiedenmann, K. Detjen, and T. Cramer. 2008. Hypoxia-in- 
ducible factor 1alpha mediates anoikis resistance via suppression of alpha5 integrin. Cancer Res. 68, 10113-10120.

16. Ryu, M. H., H. M. Park, J. Chung, C. H. Lee, and H. R. Park. 2010. Hypoxia-inducible factor-1alpha mediates oral squamous cell carcinoma invasion via upregulation of alpha5 integrin and fibronectin. Biochem Biophys. Res. Commun. 393, 11-15.

17. Sloan, E. K., N. Pouliot, K. L. Stanley, J. Chia, J. M. Moseley, D. K. Hards, and R. L. Anderson. 2006. Tumor-specific expression of alphavbeta3 integrin promotes spontaneous metastasis of breast cancer to bone. Breast Cancer Res. 8, R20.

18. Song, G., Q. F. Cai, Y. B. Mao, Y. L. Ming, S. D. Bao, and G. L. Ouyang. 2008. Osteopontin promotes ovarian cancer progression and cell survival and increases HIF-1alpha expression through the PI3-K/Akt pathway. Cancer Sci. 99, 1901-1907.

19. Stemmer, V., B. De Craene, G. Berx, and J. Behrens. 2008. Snail promotes Wnt target gene expression and interacts with beta-catenin. Oncogene 27, 5075-5080.

20. Strutz, F., H. Okada, C. W. Lo, T. Danoff, R. L. Carone, J. E. Tomaszewski, and E. G. Nelson. 1995. Identification and characterization of a fibroblast marker: FSP1. J. Cell Biol. 130, 393-405.

21. Vuoriluoto, K., H. Haugen, S. Kiviluoto, J. P. Mpindi,J. Nevo, C. Gjerdrum, C. Tiron, J. B. Lorens, and J. Ivaska. 2010. Vimentin regulates EMT induction by Slug and oncogenic H-Ras and migration by governing Axl expression in breast cancer. Oncogene 8, Epub ahead of print.

22. Wang, Y., V. N. Ngo, M. Marani, Y. Yang, G, Wright, L.
M. Staudt, and J. Downward. 2010. Critical role for transcriptional repressor Snail2 in transformation by oncogenic RAS in colorectal carcinoma cells. Oncogene 29, 4658-4670.

23. Wang, Z., Y. Li, D. Kong, and F. H. Sarkar. 2010. The role of Notch signaling pathway in epithelial-mesenchymal transition (EMT) during development and tumor aggressiveness. Curr. Drug Targets 11, 745-751.

24. Wietrzyk, J., B. Filip, M. Milczarek, D. Klopotowska, M. Maciejewska, K. Dabrowska, A. Kurzepa, S. Dzimira, J. Madej, and A. Kutner. 2008. The influence of 1,25-dihydroxyvitamin D3 and 1,24-dihydroxyvitamin D3 on alphavbeta3 integrin expression in cancer cell lines. Oncol. Rep. 20, 941-952.

25. Yang, J. and Y. Liu. 2001. Dissection of key events in tubular epithelial to myofibroblast transition and its implications in renal interstitial fibrosis. Am J. Pathol. 159, 1465-1475.

26. Yan, W., Y. Fu, D. Tian, J. Liao, M. Liu, B. Wang, L. Xia, Q. Zhu, and M. Luo. 2009. PI3 kinase/Akt signaling mediates epithelial-mesenchymal transition in hypoxic hepatocellular carcinoma cells. Biochem Biophys. Res. Commun. 382, 631-636.

27. Yoon, S. O., S. Shin, and A. M. Mercurio. 2005. Hypoxia stimulates carcinoma invasion by stabilizing microtubules and promoting the Rab11 trafficking of the alpha6beta4 integrin. Cancer Res. 65, 2761-2769.

28. Zhang, L. and R. P. Hill. 2007. Hypoxia enhances metastatic efficiency in HT1080 fibrosarcoma cells by increasing cell survival in lungs, not cell adhesion and invasion. Cancer Res. 67, 7789-7797.

\section{초록 : Cobalt chloride에 의해 유도되는 상피-중간엽 이행에서의 국소부착 단백질의 인산화의 역할 규명 남주옥*}

(경북대학교 생태환경보전학과)

본 연구는 인간 폐암세포의 저산소 상태를 재현하기 위한 $\mathrm{CoCl}_{2}$ 의 처리 조건을 최적화 하였고, 최적화 된 저산 소 상태에서 인간 폐암세포의 암화 과정 및 기전을 규명하였다. 인간 폐암세포, $\mathrm{A} 549$ 와 $\mathrm{H} 460$ 에 $500 \mu \mathrm{M} \mathrm{CoCl}$ 를 24시간 처리하였을 때 저산소 상태의 대표적인 전사인자, HIF-1a의 발현이 증가함을 확인하였고 인간 폐암세포 들의 성장에는 전혀 영향을 미치지 않음을 확인하였다. 또한 $\mathrm{CoCl}_{2}$ 를 처리한 인간 폐암 세포에서 상피-중간엽 이행(epithelial-to-mesenchymal-like transition)의 대표적인 마커인 E-cadherin 발현의 감소와 a-SMA의 증가를 확인하였고, 세포-세포 간 junction 부위가 깨어짐을 E-cadherin 형광염색 실험을 통하여 확인하였다. 더 나아가 $\mathrm{CoCl}_{2}$ 를 처리한 인간 폐암 세포에서 상피-중간엽 이행의 분자적 기전을 밝히기 위해 세포벽에 존재하는 인테그린 (integrin)의 발현을 웨스턴 블랏팅과 $\mathrm{FACS}$ 분석을 통하여 알아본 결과, $\mathrm{CoCl}_{2}$ 를 처리한 인간 폐암세포에서 인테 그린 $\beta 3$ 발현의 증가를 확인하였다. 뿐만 아니라, $\mathrm{CoCl}_{2}$ 를 처리한 인간 폐암세포에서 인테그린 $\beta 3$ 의 하부 신호전 달 물질인 국소부착 카이네이즈(FAK)의 인산화가 증가함을 확인하였다. 상기의 결과로서, 국소부착 카이네이즈 의 인산화를 저해함으로써 인간 폐암세포가 악성세포로 전이되는 것을 저해할 수 있을 것으로 기대 되어진다. 